\title{
New Algorithm of Clay CEC for Soils in Tropical and Subtropical Regions of South China
}

\author{
Xiangzheng Kong1,2, Decheng $\mathrm{Li}^{1}{ }^{*}$, Xiaodong Song1, Ganlin Zhang ${ }^{1}$ \\ ${ }^{1}$ State Key Laboratory of Soil and Sustainable Agriculture, Institute of Soil Science, Chinese Academy of Sciences, Nanjing, China \\ ${ }^{2}$ University of Chinese Academy of Sciences, Beijing, China \\ Email: kongxiangzhen@issas.ac.cn, ${ }^{\star}$ dcli@issas.ac.cn
}

How to cite this paper: Kong, X.Z., Li, D.C., Song, X.D. and Zhang, G.L. (2021) New Algorithm of Clay CEC for Soils in Tropical and Subtropical Regions of South China. Agricultural Sciences, 12, 1048-1057. https://doi.org/10.4236/as.2021.1210067

Received: August 10, 2021

Accepted: October 9, 2021

Published: October 12, 2021

Copyright $\odot 2021$ by author(s) and Scientific Research Publishing Inc. This work is licensed under the Creative Commons Attribution-NonCommercial International License (CC BY-NC 4.0).

http://creativecommons.org/licenses/by-nc/4.0/ (c) (i) (8) Open Access

\begin{abstract}
Clay CEC is one of identification indexes of the LAC-ferric horizon which is the diagnostic horizon of ferrosols in Chinese Soil Taxonomy, and it is defined as soil CEC $\times 1000 /$ clay content, rather than the measured CEC of the extracted clays; however, such a calculation method would definitely lead to an overestimation of clay CEC because it doesn't remove the contribution to soil CEC from other soil parameters. In this study, the physiochemical data of the subhorizons from 82 soil series in the tropical and subtropical regions in south China were used, clay CEC was calculated according to the current formula and measured after clays being extracted, the measured and calculated clay CEC were compared, the influencing factors were analyzed for their difference, and the new algorithms were established for clay CEC. The results showed that the measured clay CEC was $21.86 \%-99.53 \%$ with a mean of $66.88 \%$ of the calculated one (significantly lower at $\mathrm{p}<0.01$ ), and their difference was significantly correlated with the contents of clays, sand and OM, and mainly decided by the contents of clays and $\mathrm{Fe}_{2} \mathrm{O}_{3}$ (the contribution was $52.51 \%$ and $25.36 \%$, respectively). By comparison of established regression models of clay CEC with other soil parameters, two new algorithms were recommended for clay CEC as follows: 1) Clay CEC $=10.32-0.14 \mathrm{pH}-$ $0.05 \mathrm{OM}-0.11 \mathrm{Fe}_{2} \mathrm{O}_{3}+0.01$ Silt -0.01 Clay $+1.17 \mathrm{CEC}_{\text {soil }}, \mathrm{R}^{2}=0.705, \mathrm{P}<0.01$;

2) Clay CEC $=-3.40+0.01$ Sand +0.02 Silt +1.05 CEC $_{\text {soil }}, \mathrm{R}^{2}=0.589, \mathrm{P}<$ $0.01)$.
\end{abstract}

\section{Keywords}

Measured Clay CEC, Calculated Clay CEC, Algorithm, Subhorizon Soil, South China 


\section{Introduction}

Ferrosols is one of soil orders in Chinese Soil Taxonomy (CST) [1], which is a soil order between argosols whose main process is the accumulation of higher activity clays and ferralosols which has a higher degree of ferrallitization. Low activity clay-ferric horizon (LAC-ferric horizon) is the diagnostic horizon of ferrosols, characterized by the medium degree of ferrallitization, lower activity clays and rich in free iron oxides [2] [3]. One of the definitions of LAX-ferric horizon is that clay CEC is less than $24 \mathrm{cmol}(+) / \mathrm{kg}$ in partial subhorizons $(10 \mathrm{~cm}$ or more thick) [1]. However, in CST, clay CEC is calculated by soil CEC $\times$ $1000 /$ clay content, rather than the measurement of the extracted clays. Obviously, the underlying assumption of the above formula is that the influences of other soil parameters ( $\mathrm{pH}, \mathrm{SOM}$, particle composition, etc.) on soil CEC can be ignored in the highly-weathered subhorizons in tropical and subtropical regions of south China. However, some studies found such a presupposition unreliable or unacceptable [4] [5], and it would doubtlessly overestimate clay CEC, thus, would lead to the misidentification of soil types [5].

Because the recent study on the prediction models of clay CEC [5] failed to cover all the tropical and subtropical regions in south China, soil samples used for modeling with high SOM content $\left(\geq 6 \mathrm{~g} \cdot \mathrm{kg}^{-1}\right)$ were limited, and the average annual temperature, roughly obtained by spatial interpolation, was included in the prediction model with low SOM content $\left(<6 \mathrm{~g} \cdot \mathrm{kg}^{-1}\right)$, so the accuracy of the models would be influenced or reduced. Thus, in this study the physiochemical data of the typical subhorizons from 82 soil series in the tropical and subtropical regions of south China were used to: 1 ) disclose further the difference between the measured and calculated clay CEC, 2) clarify the influences of other soil parameters on the difference, and 3) setup new algorithms for clay CEC.

\section{Materials and Methods}

\subsection{Background of Tested Soil Samples}

Figure 1 shows the spatial distribution of used 82 soil series in the tropical and subtropical regions of south China [6]-[16]. For a soil sample, the pipette method was used to separate and obtain clays and silts and to determine the particle size distribution, the potentiometer method (soil:water $=1: 2.5$ ) was used to measure $\mathrm{pH}$, the Walkley-Black wet oxidation method was used to measure OM content, the phenanthroline colorimetry method was used to determine free $\mathrm{Fe}_{2} \mathrm{O}_{3}$ content, the $\mathrm{NH}_{4} \mathrm{OAc}(\mathrm{pH}=7.0)$ exchange method was used to measure CEC of soil, clays and silts [17] [18] [19].

\subsection{Data Statistical Analysis}

Microsoft Excel 2016 and IBM Statistics SPSS 22.0 software were used for statistical analysis of the data, and Duncan test method (2-tailed) was used for variance analyses and multiple comparisons. 


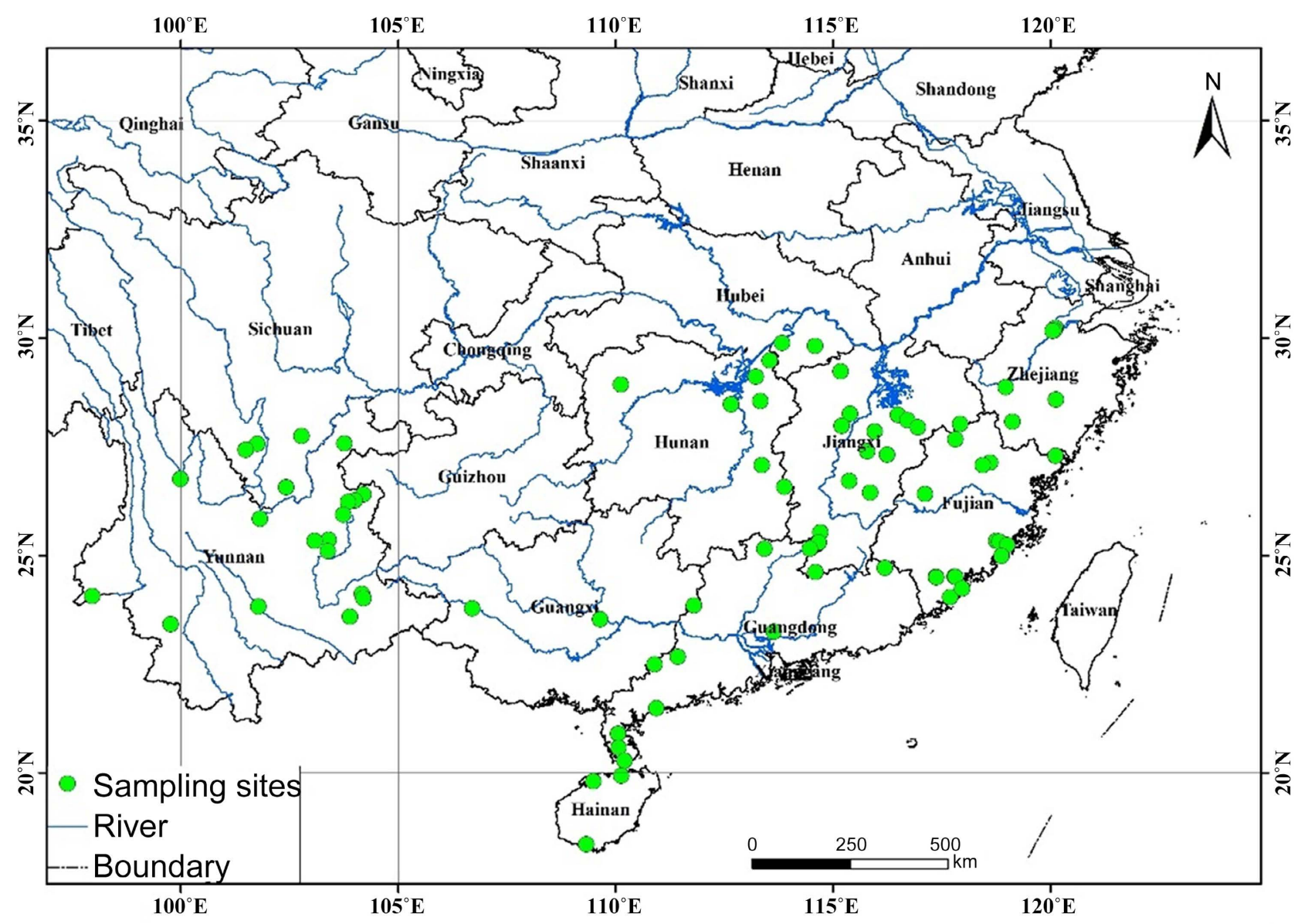

Figure 1. Spatial distribution of used 82 soil series in tropical and subtropical regions of south China.

\section{Results}

\subsection{Statistical Results of Soil Physiochemical Parameters}

Table 1 lists the measured values of soil physiochemical parameters, it showed that soil CEC was ranged from 5.12 to $20.29 \mathrm{cmol}(+) \cdot \mathrm{kg}^{-1}$ with a mean of 11.92 $\mathrm{cmol}(+) \cdot \mathrm{kg}^{-1}$, measured clay CEC (Clay $\mathrm{CEC}_{\mathrm{m}}$ ) was ranged from 7.51 to 34.87 $\mathrm{cmol}(+) \cdot \mathrm{kg}^{-1}$ with a mean of $20.03 \mathrm{cmol}(+) \cdot \mathrm{kg}^{-1}$, calculated clay CEC (clay $\mathrm{CEC}_{\mathrm{c}}$ ) was ranged from 12.34 to $92.15 \mathrm{cmol}(+) \cdot \mathrm{kg}^{-1}$ with a mean of $32.43 \mathrm{cmol}(+) \cdot \mathrm{kg}^{-1}$, silt CEC was ranged from 0.48 to $12.72 \mathrm{cmol}(+) \cdot \mathrm{kg}^{-1}$ with a mean of 4.83 $\mathrm{cmol}(+) \cdot \mathrm{kg}^{-1}$. Comparatively, clay $\mathrm{CEC}_{\mathrm{m}}$ was $21.86 \%-99.53 \%$ with a mean of $66.88 \%$ of clay $\mathrm{CEC}_{c}$, significantly lower at $\mathrm{p}<0.01$.

\subsection{Parameters Influencing CEC}

Table 2 lists Pearson correlation between CEC and other parameters. It can be found that $\mathrm{pH}$ had no significant correlation with $\mathrm{CEC}$, OM had significant positive correlation with clay $\mathrm{CEC}_{\mathrm{c}}$ and $\Delta$ clay CEC [(clay $\mathrm{CEC}_{\mathrm{c}}-$ clay $\left.\mathrm{CEC}_{\mathrm{m}}\right) /$ clay $\mathrm{CEC}_{\mathrm{c}}$ ] $(\mathrm{p}<0.01)$, free $\mathrm{Fe}_{2} \mathrm{O}_{3}$ had significant positive correlation with soil CEC ( $\mathrm{p}$ $<0.01)$ and silt CEC $(\mathrm{p}<0.05)$, sand content had significant negative correlation with soil CEC $(\mathrm{p}<0.01)$ and clay $\mathrm{CEC}_{\mathrm{m}}(\mathrm{p}<0.05)$ but had significant positive 
Table 1. Statistical descriptions of soil chemical properties $(n=82)$.

\begin{tabular}{ccccccc}
\hline Soil parameter & Min. & Max. & Mean \pm S.D. & C.V. (\%) & Skewness & Kurtosis \\
\hline Soil CEC & 5.12 & 20.29 & $11.92 \pm 3.73$ & 31.33 & 0.35 & -0.66 \\
Clay CEC $_{m}$ & 7.51 & 34.87 & $20.03 \pm 5.52 \mathrm{~A}$ & 27.57 & 0.09 & -0.43 \\
$\mathrm{Clay} \mathrm{CEC} c$ & 12.34 & 92.15 & $32.43 \pm 14.32 \mathrm{~B}$ & 44.14 & 1.94 & 5.13 \\
Silt CEC & 0.48 & 12.72 & $4.83 \pm 2.87$ & 59.51 & 0.67 & -0.34 \\
$\mathrm{pH}$ & 3.73 & 6.77 & $5.11 \pm 0.62$ & 12.14 & 0.76 & 0.29 \\
$\mathrm{OM}$ & 2.41 & 33.57 & $8.8 \pm 5.89$ & 66.38 & 1.80 & 3.69 \\
Free Fe $2 \mathrm{O}_{3}$ & 20.84 & 105.96 & $44.70 \pm 18.31$ & 40.95 & 1.03 & 0.54 \\
Sand & 67.00 & 634.00 & $296 \pm 147$ & 49.55 & 0.35 & -0.74 \\
Silt & 84.00 & 517.00 & $308 \pm 105$ & 34.17 & 0.08 & -0.71 \\
Clay & 127.00 & 707.00 & $396 \pm 118$ & 29.90 & 0.34 & 0.46 \\
\hline
\end{tabular}

Note: 1) CEC, $\mathrm{cmol}(+) \cdot \mathrm{kg}^{-1}$; sand, silt, clay, $\mathrm{OM}$ and free $\left.\mathrm{Fe}_{2} \mathrm{O}_{3}, \mathrm{~g} \cdot \mathrm{kg}^{-1} ; 2\right)$ Clay $\mathrm{CEC}_{\mathrm{m}}$, measured $\mathrm{CEC}$ of extracted clays; Clay $\mathrm{CEC}_{\mathrm{c}}$, calculated clay CEC by soil CEC $\times 100 /$ clay content; Silt CEC, measured CEC of extracted silts; 3) Data of Clay $\mathrm{CEC}_{\mathrm{m}}$ and $\mathrm{CEC}_{\mathrm{c}}$ followed by different capitals are significantly different at $\mathrm{p}$ $<0.01$ level.

Table 2. Pearson correlation between soil CEC and other parameters.

\begin{tabular}{ccccccccc}
\hline CEC & Correlation & $\mathrm{pH}$ & $\mathrm{OM}$ & ${\mathrm{Free} \mathrm{Fe}_{2} \mathrm{O}_{3}}$ & Sand & Silt & Clay \\
\hline Soil CEC & Pearson Correlation & 0.016 & 0.089 & $0.332^{* *}$ & $-0.383^{* *}$ & 0.184 & $0.310^{* *}$ \\
& Sig. (2-tailed) & 0.884 & 0.417 & 0.002 & 0.000 & 0.091 & 0.004 \\
\hline Clay CEC $m$ & Pearson Correlation & -0.033 & -0.007 & -0.160 & $-0.231^{*}$ & $0.397^{* *}$ & -0.066 \\
& Sig. (2-tailed) & 0.765 & 0.952 & 0.144 & 0.033 & 0.000 & 0.546 \\
\hline Clay CEC $c$ & Pearson Correlation & -0.028 & $0.416^{* *}$ & 0.007 & $0.223^{*}$ & $0.313^{* *}$ & $-0.554^{* *}$ \\
& Sig. (2-tailed) & 0.797 & 0.000 & 0.949 & 0.040 & 0.004 & 0.000 \\
\hline \multicolumn{1}{c}{ clay CEC significant positive } & Pearson Correlation & 0.005 & $0.399^{* *}$ & 0.068 & $0.472^{* *}$ & 0.034 & $-0.615^{* *}$ \\
& Sig. (2-tailed) & 0.962 & 0.000 & 0.537 & 0.000 & 0.756 & 0.000 \\
\hline Silt CEC & Pearson Correlation & -0.165 & 0.173 & $0.251^{*}$ & 0.121 & 0.084 & $-0.226^{*}$ \\
& Sig. (2-tailed) & 0.131 & 0.114 & 0.020 & 0.269 & 0.442 & 0.038 \\
\hline
\end{tabular}

Note: 1$)^{\star} . * *$, Correlation is significant at $\mathrm{p}<0.05$ or 0.01 level $(2$-tailed $\left.) ; 2\right) \Delta$ clay CEC $=\left(\right.$ clay $\mathrm{CEC}_{\mathrm{c}}-$ clay $\left.\mathrm{CEC}_{\mathrm{m}}\right) /$ clay $\mathrm{CEC}_{\mathrm{c}}$.

correlation with clay $\mathrm{CEC}_{\mathrm{c}}(\mathrm{p}<0.05)$ and $\Delta$ clay CEC $(\mathrm{p}<0.01)$, silt content had significant positive correlation with clay $\mathrm{CEC}_{\mathrm{m}}$ and $\mathrm{CEC}_{\mathrm{c}}(\mathrm{p}<0.01)$, clay content had significant positive correlation with soil CEC $(\mathrm{p}<0.01)$ but had significant negative correlation with clay $\operatorname{CEC}_{\mathrm{c}}(\mathrm{p}<0.01), \Delta$ clay CEC $(\mathrm{p}<0.01)$ and silt CEC $(\mathrm{p}<0.05)$.

The contribution of one parameter to CEC was calculated as the follows: firstly, all parameters were normalized by the Z-score method with IBM Statistics SPSS 20.0 to ensure them with the same magnitude, and then the regression coefficients between each parameter and CEC was used to indicate their contri- 
bution to CEC [20] [21] [22]. The contribution of one parameter $\left(C_{i}\right)$ to CEC was calculated as $C_{i}=\left|K_{i}\right|\left|K_{\text {sum }}\right|$, in which $K_{i}$ is the regression coefficient of the $i$ parameter, and $K_{\text {sum }}$ is the total sum of all coefficients, the obtained linear regression models of CEC with other parameters were listed in Table 3, and the calculated contribution of other parameters to CEC were listed in Table 4.

In view of the contribution of other parameters to CEC, it can be seen from Table 4 that soil CEC was mainly decided by clays (34.29\%), followed by silt content (25.75\%) and free $\mathrm{Fe}_{2} \mathrm{O}_{3}$ (21.75\%); clay $\mathrm{CEC}_{\mathrm{m}}$ was mainly determined by silt content (51.34\%), followed by free $\mathrm{Fe}_{2} \mathrm{O}_{3}(26.34 \%)$; clay $\mathrm{CEC}_{c}$ was mainly influenced by clay content (46.96\%), followed by SOM (18.53\%), silt content (17.20\%) and free $\mathrm{Fe}_{2} \mathrm{O}_{3}$ (16.64\%); $\Delta$ clay CEC was mainly affected by clay content (52.51\%), followed by free $\mathrm{Fe}_{2} \mathrm{O}_{3}(25.36 \%)$; silt $\mathrm{CEC}_{\mathrm{m}}$ was mainly determined by free $\mathrm{Fe}_{2} \mathrm{O}_{3}(39.82 \%)$ and clay content (35.17\%), followed by $\mathrm{pH}(17.34 \%)$.

\subsection{New Algorithms for Clay CEC}

Table 5 lists the correlation between clay $\mathrm{CEC}_{\mathrm{m}}$ and other properties, it can be found from Table 5 that clay $\mathrm{CEC}_{\mathrm{m}}$ had significant positive correlation with silt content, soil CEC and clay $\mathrm{CEC}_{\mathrm{c}}(\mathrm{p}<0.01)$ but had significant negative correlation with sand content $(\mathrm{p}<0.05)$. By using IBM Statistics SPSS, the regression models of clay $\mathrm{CEC}_{\mathrm{m}}$ with other parameters were obtained (see Table 6), and it could be found by comparison from Table 6 that Model 6 and 5 could be recommended as the new algorithms for clay CEC.

\section{Discussions}

\subsection{Statistical Results of Soil Physiochemical Properties}

Our study showed (see Table 1) that, for the subhorizons of highly-weathered

Table 3. Linear regression model between normalized CEC and other soil properties.

\begin{tabular}{|c|c|c|c|c|}
\hline Linear regression model & $\mathrm{R}^{2}$ & RMSE & $\mathrm{F}$ & Sig. \\
\hline Soil CEC $=-0.060 \mathrm{pH}+0.093 \mathrm{OM}+0.183 \mathrm{Fe}_{2} \mathrm{O}_{3}+0.217 \mathrm{Silt}+0.289 \mathrm{Clay}-3.187 \times 10^{-16}$ & 0.198 & 0.92 & 3.90 & 0.003 \\
\hline Clay $\mathrm{CEC}_{\mathrm{m}}=-0.063 \mathrm{pH}+0.020 \mathrm{OM}-0.220 \mathrm{Fe}_{2} \mathrm{O}_{3}+0.429$ Silt $+0.103 \mathrm{Clay}-6.634 \times 10^{-16}$ & 0.201 & 0.92 & 3.96 & 0.003 \\
\hline Clay $\mathrm{CEC}_{\mathrm{c}}=-0.008 \mathrm{pH}+0.221 \mathrm{OM}+0.198 \mathrm{Fe}_{2} \mathrm{O}_{3}+0.205$ Silt -0.559 Clay $-7.710 \times 10^{-16}$ & 0.467 & 0.75 & 13.86 & 0.000 \\
\hline$\Delta$ clay $\mathrm{CEC}=0.054 \mathrm{pH}+0.154 \mathrm{OM}+0.368 \mathrm{Fe}_{2} \mathrm{O}_{3}-0.114$ Silt -0.763 Clay $-5.316 \times 10^{-16}$ & 0.552 & 0.69 & 19.48 & 0.000 \\
\hline Silt $\mathrm{CEC}=-0.211 \mathrm{pH}-0.060 \mathrm{OM}+0.485 \mathrm{Fe}_{2} \mathrm{O}_{3}+0.033$ Silt $-0.428 \mathrm{Clay}-3.603 \times 10^{-16}$ & 0.246 & 0.90 & 5.15 & 0.000 \\
\hline
\end{tabular}

Table 4. Contribution of other soil properties to CEC (\%).

\begin{tabular}{cccccccc}
\hline Property & $\mathrm{pH}$ & $\mathrm{OM}$ & Free $\mathrm{Fe}_{2} \mathrm{O}_{3}$ & Sand & Silt & Clay & Total \\
\hline Soil CEC & 7.12 & 11.09 & 21.75 & 0 & 25.75 & 34.29 & 100.00 \\
Clay CEC $_{\mathrm{m}}$ & 7.54 & 2.41 & 26.34 & 0 & 51.34 & 12.36 & 100.00 \\
Clay CEC $_{\mathrm{c}}$ & 0.67 & 18.53 & 16.64 & 0 & 17.20 & 46.95 & 100.00 \\
$\Delta \mathrm{CEC}$ & 3.69 & 10.59 & 25.36 & 0 & 7.85 & 52.51 & 100.00 \\
Silt CEC & 17.34 & 4.93 & 39.82 & 0 & 2.74 & 35.17 & 100.00 \\
\hline
\end{tabular}


Table 5. Pearson correlation between clay $\mathrm{CEC}_{\mathrm{m}}\left(\mathrm{Clay}_{\mathrm{CEC}}\right)$ and other parameters.

\begin{tabular}{cccccccccc}
\hline & $\mathrm{pH}$ & $\mathrm{OM}$ & $\mathrm{Fe}_{2} \mathrm{O}_{3}$ & Sand & Silt & Clay & $\mathrm{CEC}_{\text {soil }}$ & $\mathrm{CEC}_{\text {silt }}$ & $\mathrm{CEC}_{\text {clay-c }}$ \\
\hline Pearson Correlation & -0.033 & -0.007 & -0.160 & $-0.231^{*}$ & $0.397^{* *}$ & -0.066 & $0.675^{* *}$ & -0.009 & $0.521^{* *}$ \\
Sig. (2-tailed) & 0.765 & 0.952 & 0.144 & 0.033 & 0.000 & 0.546 & 0.000 & 0.937 & 0.000 \\
\hline
\end{tabular}

Note: 1$) *{ }^{* *}$, Correlation is significant at $\mathrm{p}<0.05$ or 0.01 level (2-tailed); 2) CECsoil, measured soil CEC; $\mathrm{CEC}_{\text {silt, }}$ measured silt CEC; $\mathrm{CEC}_{\text {clay-c, }}$, calculated clay CEC (soil CEC $\times 1000$ /clay content). The same below.

Table 6. Predicting models of clay $\mathrm{CEC}_{7}$.

\begin{tabular}{rlcccc}
\hline \multicolumn{1}{c}{ Model } & $\mathrm{R}^{2}$ & RMSE & $\mathrm{F}$ & Sig. \\
\hline 1 & Clay CEC $=19.86-6.46 \times 10^{-8} \mathrm{Sand}^{3}+1.32 \times 10^{-5} \mathrm{Sand}^{2}+0.01$ Sand & 0.102 & 5.33 & 3.08 & 0.032 \\
2 & Clay CEC $=5.09+5.14 \times 10^{-7} \mathrm{Silt}^{3}+0.14 \mathrm{Silt}$ & 0.180 & 5.09 & 5.92 & 0.001 \\
3 & Clay CEC $=11.47-0.01 \mathrm{CEC}_{\text {soil }}^{3}+0.17 \mathrm{CEC}_{\text {soil }}^{2}-0.47 \mathrm{CEC}_{\text {soil }}$ & 0.473 & 4.08 & 24.20 & 0.000 \\
4 & Clay CEC $=-12.66-0.04 \mathrm{CEC}_{\text {clay-c }}^{2}+2.11 \mathrm{CEC}_{\text {clay }-\mathrm{c}}$ & 0.437 & 4.22 & 20.92 & 0.000 \\
5 & Clay CEC $=-3.40+0.01 \mathrm{Sand}+0.02 \mathrm{Silt}+1.05 \mathrm{CEC}_{\text {soil }}$ & 0.589 & 3.61 & 38.64 & 0.000 \\
6 & Clay CEC $=10.32-0.14 \mathrm{pH}-0.05 \mathrm{OM}-0.11 \mathrm{Fe}_{2} \mathrm{O}_{3}+0.01$ Silt -0.01 Clay $+1.17 \mathrm{CEC}_{\text {soil }}$ & 0.705 & 3.11 & 31.07 & 0.000 \\
\hline
\end{tabular}

Note: $\mathrm{CEC}_{\text {soil, }}$ soil $\mathrm{CEC}_{7} ; \mathrm{CEC}_{\text {clay-m}}$, measured Clay $\mathrm{CEC}$; $\mathrm{CEC}_{\text {silt }}$, measured silt $\mathrm{CEC}$.

acid soils in the tropical and subtropical regions in south China, clay content was meanly $396 \mathrm{~g} \cdot \mathrm{kg}^{-1}$ while sand content was meanly $296 \mathrm{~g} \cdot \mathrm{kg}^{-1}$; Meanwhile, free $\mathrm{Fe}_{2} \mathrm{O}_{3}$

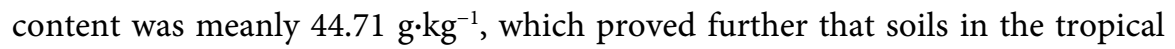
and subtropical regions of south China are clayey and rich in free $\mathrm{Fe}_{2} \mathrm{O}_{3}[23]$.

\subsection{Difference between Measured and Calculated Clay CEC}

Our study also showed that, for the subhorizons of highly-weathered soils in the tropical and subtropical regions in south China, the measured clay CEC was $21.86 \%-99.53 \%$ with a mean of $66.88 \%$ lower than the calculated clay CEC (significantly lower at $\mathrm{p}<0.01$ ), which was $8.61 \%-90.78 \%$ with a mean of $62.42 \%$ in the study of Yang et al. [5]. Such a difference could be attributed to the removal of the contribution to soil CEC from other soil parameters (mainly from silts, see Table 2) in calculating clay CEC. For example, our study showed that silt CEC was ranged from 0.48 to $12.72 \mathrm{cmol}(+) \cdot \mathrm{kg}^{-1}$ with a mean of 4.83 $\mathrm{cmol}(+) \cdot \mathrm{kg}^{-1}$, which accorded with the reports of Zhang and Zhu [4] and Yang et al. [5], it proved further that silts in the subhorizons could also influence soil CEC in the tropical and subtropical regions of south China, which mainly was attributed to the 2:1 clay minerals such as vermiculite and mica in silts [4]. Our study disclosed further the influencing factors of the differences between the measured and calculated clay CEC, which was mainly decided by clay content (52.51\%), followed by free $\mathrm{Fe}_{2} \mathrm{O}_{3}(25.36 \%), \mathrm{OM}$ (10.59\%), silt content (7.85\%) and $\mathrm{pH}(3.69 \%)$, but no effect from sand content.

\subsection{Parameters Influencing CEC}

Previous studies showed that $\mathrm{pH}$ usually has positive correlation with soil CEC 
for acid soils [20] [24] [25] [26] [27], however, no significant positive correlation was found in our study between $\mathrm{pH}$ and soil CEC ( $\mathrm{R}$ was $0.016, \mathrm{p}=0.884$ ), which could be attributed to narrow range of $\mathrm{pH}$ of the soil samples used in our study (acid, 3.73 - 6.77 with a mean of 5.11). SOM usually has significant positive correlation with soil CEC [20] [24]-[35], but our results showed that SOM had no significant correlation with soil CEC ( $\mathrm{R}$ was $0.089, \mathrm{p}=0.417$ ), which could be related to the low SOM content [29] [32] [33] [36] in subhorizon soils in the subtropical and tropical regions of south China (in our study, OM was $2.41-33.57 \mathrm{~g} \cdot \mathrm{kg}^{-1}$ with a mean of $\left.8.8 \mathrm{~g} \cdot \mathrm{kg}^{-1}\right)$. Clay content usually also has significant positive correlation with soil CEC [20] [24] [25] [26] [27] [29]-[35] [37], our results also showed this tendency ( $\mathrm{R}$ was $0.310, \mathrm{p}<0.01$ ). Our study found that free $\mathrm{Fe}_{2} \mathrm{O}_{3}$ was significantly correlated with soil CEC ( $\mathrm{R}$ was $0.332, \mathrm{p}<0.01$ ), few studies analyzed the correlation between free $\mathrm{Fe}_{2} \mathrm{O}_{3}$ and soil CEC because free $\mathrm{Fe}_{2} \mathrm{O}_{3}$ in subtropical and tropical highly-weathered soils usually exist as clay fraction or strongly cemented with clays [23] [38] [39] [40], so more attentions were paid to the correlation between clay content rather than free $\mathrm{Fe}_{2} \mathrm{O}_{3}$ with soil CEC. Our study also found that soil CEC had negative correlation with sand content, which is consistent with the previous studies [24] [33] [35] [36] [37], and could be attributed to sand fraction mainly composed of quartz and iron concretions with low charge density [41] in subtropical and tropical humid climate soils. However, our study found no significant positive correlation between soil CEC with silt content as found in other studies [20] [25] although it also could influence soil CEC as clays as found in our study and other studies [4] [5].

\subsection{Recommendation Using $\mathrm{CEC}_{2}$ Predicting Model for Soil Taxonomy}

Our study showed that, for the subhorizons of the highly-weathered acid soils in the tropical and subtropical regions of south China, the calculated clay CEC (soil CEC $\times 1000$ /clay content, [1]) was significantly higher than the measured one (see Table 1), this obvious overestimation of clay CEC is most likely to lead to some authentic LAC-ferric horizons being misjudged as other diagnostic horizons, thus leading to misjudgment of soil types [4] [5].

Extracting clay and measuring its CEC is a very tedious and troublesome process, so it is helpful and necessary to find a new algorithm for clay CEC in order to ensure the identification accuracy of soil types in the tropical and subtropical regions. In our study, various regression models between measured clay CEC and other parameters were established, and it was found that model with only one parameter usually was lower in accuracy. By comparison, two optimal models are recommended as new algorithms for clay CEC, in which one included $\mathrm{pH}$, the contents of OM, silts, clays and soil CEC (Model 6, $\mathrm{R}^{2}=0.705, \mathrm{P}$ $<0.01$, see Table 6), and the other included sand and silt contents and soil CEC (Model 5, $\mathrm{R}^{2}=0.589, \mathrm{p}<0.01$, see Table 6). 


\section{Conclusion}

Our study quantitatively proved that for the highly-weathered subhorizons in the tropical and subtropical regions of south China, the measured clay CEC $\left(\mathrm{NH}_{4} \mathrm{OAc}, \mathrm{pH}=7.0\right)$ was significantly lower than the calculated one (soil CEC $\times$ $1000 /$ clay content), their difference was significantly correlated with the contents of clays, sands and OM, but mainly decided by the contents of clays and free $\mathrm{Fe}_{2} \mathrm{O}_{3}$. For higher accuracy in predicting clay CEC, more other soil parameters should be included in the new algorithms for clay CEC.

\section{Acknowledgements}

This study was supported by projects of the National Natural Science Foundation of China (No. 41877008) and the National S\&T Basic Special Foundation Project (No. 2014FY110200). We would like to express thanks to the contribution of all colleagues in the data preparation and the establishment of the soil series.

\section{Conflicts of Interest}

The authors declare no conflicts of interest regarding the publication of this paper.

\section{References}

[1] CRG-CST (2001) Chinese Soil Taxonomy. Science Press, Beijing.

[2] Shi, X.Z., Chen, Z.C., Zhang, J.M., et al. (1995) Rationale for Concepts of Ferrisols, Luvisols and Cambisols in Chinese Soil Taxonomic Classification. Acta Pedologica Sinica, 32, 12-20. (In Chinese)

[3] Zhao, W.J. and Chen, Z.C. (1995) Establishment of Ferrisol Order in Chinese Soil Taxonomic Classification. Acta Pedologica Sinica, 32, 21-33. (In Chinese)

[4] Zhang, M.K. and Zhu, Z.X. (1993) Effect of Slits on Cation Exchange Capacity of Soils. Soils and Fertilizers, 4, 41-43. (In Chinese)

[5] Yang, J.W., Wang, T.W., Bao, Y.Y., et al. (2021) Optimization of the Model for Predicting Cation Exchange Capacity of Clays. Acta Pedologica Sinica, 58, 514-525. (In Chinese)

[6] Lu. Y. (2017) Soil Series of China. Guangdong Volume. Science Press, Beijing. (In Chinese)

[7] Wang, T.W. and Chen, J.Y. (2020) Soil Series of China. Jiangxi Volume. Science Press, Beijing. (In Chinese)

[8] Zhang, M.K. and Ma, W.C. (2017) Soil Series of China. Fujian Volume. Science Press, Beijing. (In Chinese)

[9] Zhang, Y.Z., Zhou, Q., Sheng, H., et al. (2020) Soil Series of China. Hunan Volume. Science Press, Beijing. (In Chinese)

[10] Ma, W.C. and Zhang, M.K. (2017) Soil Series of China. Zhejiang Volume. Science Press, Beijing. (In Chinese)

[11] Huang, B. and Lu, S.G. (2020) Soil Series of China. Yunnan Volume. Science Press, Beijing. (In Chinese) 
[12] Qi, Z.P., Wang, D.F. and Wei, Z.Y. (2018) Soil Series of China. Hainan Volume. Science Press, Beijing. (In Chinese)

[13] Lu, Y. and Wei, X.H. (2020) Soil Series of China. Guangxi Volume. Science Press, Beijing. (In Chinese)

[14] Wang, T.W. (2017) Soil Series of China. Hubei Volume. Science Press, Beijing. (In Chinese)

[15] Yuan, D.G. (2020) Soil Series of China. Sichuan Volume. Science Press, Beijing. (In Chinese)

[16] Lu. Y. and Wei, X.H. (2020) Soil Series of China. Guangxi Volume. Science Press, Beijing. (In Chinese)

[17] Zhang, G.L. and Gong, Z.T. (2012) Soil Survey Laboratory Methods. Science Press, Beijing. (In Chinese)

[18] Soil Survey Staff (2014) Kellogg Soil Survey Laboratory Methods Manual. Soil Survey Investigations Report No. 42, Version 5.0. R. Burt and Soil Survey Staff (ed.). USDA \& NRCS.

[19] Bao, S.D. (2000) Analysis for Soil and Agro-Chemistry. 3rd Edition, China Agriculture Press, Beijing. (In Chinese)

[20] Krogh, L.H., Breuning, M. and Greve, H.M. (2000) Cation-Exchange Capacity Pedotransfer Functions for Danish Soils. Acta Agriculturae Scandinavica Section B-Soil and Plant Science, 50, 1-12. https://doi.org/10.1080/090647100750014358

[21] Meghdadi, A. and Javar, N. (2018) Evaluation of Nitrate Sources and the Percent Contribution of Bacterial Denitrification in Hyporheic Zone Using Isotope Fractionation Technique and Multi-Linear Regression Analysis. Journal of Environmental Management, 222, 54-65. https://doi.org/10.1016/j.jenvman.2018.05.022

[22] Zhang, G., Liu, X., Lu, S., et al. (2020) Occurrence of Typical Antibiotics in Nansi Lake's Inflowing Rivers and Antibiotic Source Contribution to Nansi Lake Based on Principal Component Analysis-Multiple Linear Regression Model. Chemosphere, 242, Article ID: 125269. https://doi.org/10.1016/j.chemosphere.2019.125269

[23] Xiong, Y. and Li, Q.K. (1990) Soil of China. 2nd Edition, Science Press, Beijing. (In Chinese)

[24] Liao, K., Xu, S. and Zhu, Q. (2015). Development of Ensemble Pedotransfer Functions for Cation Exchange Capacity of Soils of Qingdao in China. Soil Use and Management, 31, 483-490. https://doi.org/10.1111/sum.12207

[25] Seybold, C.A., Grossman, R.B. and Reinsch, T.G. (2005) Predicting Cation Exchange Capacity for Soil Survey Using Linear Models. Soil Science Society of America Journal, 69, 856-863. https://doi.org/10.2136/sssaj2004.0026

[26] Oorts, K., Vanlauwe, B. and Merckx, R. (2003) Cation Exchange Capacities of Soil Organic Matter Fractions in A Ferric Lixisol with Different Organic Matter Inputs. Agriculture, Ecosystems \& Environment, 100, 161-171. https://doi.org/10.1016/S0167-8809(03)00190-7

[27] Meyer, W.L., Marsh, M. and Arp, P.A. (1994) Cation Exchange Capacities of Upland Soils in Eastern Canada. Canadian Journal of Soil Science, 74, 393-408. https://doi.org/10.4141/cjss94-053

[28] Zhao, J.H., Xu, B.Y., Zhao, J.J., et al. (2019). Distribution Characteristics of Soil Cation Exchange Capacity in Haxi Forest of Qilian Mountains, Gansu Province. Forest Science and Technology, 6, 41-43. (In Chinese)

[29] Shekofteh, H., Ramazani, F. and Shirani, H. (2017) Optimal Feature Selection for 
Predicting Soil CEC: Comparing the Hybrid of Ant Colony Organization Algorithm and Adaptive Network-Based Fuzzy System with Multiple Linear Regression. Geoderma, 298, 27-34. https://doi.org/10.1016/j.geoderma.2017.03.010

[30] Zhang, Q., Fang, H.L., Huang, Y.Z., et al. (2005) Application of Soil CEC to Evaluation of Soil Quality in Shanghai. Soils, 37, 679-682. (In Chinese)

[31] Li, Y., Hao, Z.K., Shi, Q., et al. (2020) Distribution Characteristics of Soil pH, Cation Exchange Capacity and Organic Matter in the Area of Western Heilongjiang Province. Protection Forest Science and Technology, No. 4, 20-22. (In Chinese)

[32] Khodaverdiloo, H., Momtaz, H. and Liao, K.H. (2018) Performance of Soil Cation Exchange Capacity Pedotransfer Function as Affected by the Inputs and Database Size. Clean-Soil Air Water, 46, Article ID: 1700670. https://doi.org/10.1002/clen.201700670

[33] Seyedmohammadi, J. and Matinfar, H.R. (2018) Statistical and Geostatistical Techniques for Geospatial Modeling of Soil Cation Exchange Capacity. Communications in Soil Science and Plant Analysis, 49, 2301-2314. https://doi.org/10.1080/00103624.2018.1499765

[34] Manrique, L.A., Jones, C.A. and Dyke, P.T. (1991) Predicting Cation-Exchange Capacity from Soil Physical and Chemical Properties. Soil Science Society of America Journal, 55, 787-794. https://doi.org/10.2136/sssaj1991.03615995005500030026x

[35] Obalum, S.E., Watanabe, Y., Igwe, C.A., et al. (2013) Improving on the Prediction of Cation Exchange Capacity for Highly Weathered and Structurally Contrasting Tropical Soils from Their Fine-Earth Fractions. Communications in Soil Science and Plant Analysis, 44, 1831-1848. https://doi.org/10.1080/00103624.2013.790401

[36] Rahal, N.S. and Alhumairi, B.A.J. (2019) Modelling of Soil Cation Exchange Capacity for Some Soils of East Gharaf Lands from Mid-Mesopotamian Plain (Wasit Province/Iraq). International Journal of Environmental Science and Technology, 16, 3183-3192. https://doi.org/10.1007/s13762-018-1913-6

[37] Khaledian, Y., Brevik, E.C., Pereira, P., et al. (2017). Modeling Soil Cation Exchange Capacity in Multiple Countries. Catena, 158, 194-200.

https://doi.org/10.1016/j.catena.2017.07.002

[38] Hu, G.C. and Zhang, M.K. (2002) Mineralogical Evidence for Strong Cementation of Soil Particles by Iron Oxides. Chinese Journal of Soil Science, 33, 25-27. (In Chinese)

[39] Martín-García, J.M., Sánchez-Marañón, M., Calero, J., et al. (2016) Iron Oxides and Rare Earth Elements in the Clay Fractions of a Soil Chronosequence in Southern Spain. European Journal of Soil Science, 67, 749-762. https://doi.org/10.1111/ejss.12377

[40] Silva, L.S., Júnior, J.M., Barrón, V., et al. (2020). Spatial Variability of Iron Oxides in Soils from Brazilian Sandstone and Basalt. Catena, 185, Article ID: 104258. https://doi.org/10.1016/j.catena.2019.104258

[41] Soares, M.R. and Alleoni, L.R.F. (2008) Contribution of Soil Organic Carbon to the Ion Exchange Capacity of Tropical Soils. Journal of Sustainable Agriculture, 32, 439-462. https://doi.org/10.1080/10440040802257348 